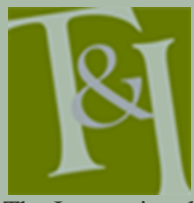

The International Journal for Translation \& Interpreting Research trans-int.org

\title{
The status of the French language in British North America: from the conquest to the confederation
}

\author{
Alexandra Hillinger \\ Université Laval, Canada \\ alexandra.hillinger@1li.ulaval.ca
}

DOI: 10.12807/ti.111202.2019.a03

\begin{abstract}
The Act of Union established English as the only official language of the legislature and of legislative documents. The Act of Union was comprised of 62 sections and over 10,000 words, yet the words "English" and "translated" are mentioned only once each. Although the Act seriously undermines the linguistic rights of French Canadians, the word "French" is nowhere to be found.

This article examines the linguistic situation of French Canadians after the Conquest of Canada by British forces in 1760. Firstly, a short history of the linguistic situation in Canada will be provided, followed by an analysis of the status of the French language in the various constitutional acts which affected the governing and the use of the French language in the territory known as Quebec. The focus will specifically be on the period surrounding the Act of Union, since the linguistic situation of French Canadians changed drastically thereafter.

Second, the linguistic policies put forward by the British Crown about the use of French in Lower Canada will also be examined. What was the status of the French language as a non-official language of the United Province of Canada? What were the linguistic barriers encountered by monolingual French speakers in Lower Canada? Therefore, one of the important aspects of this article is to examine the historical access (or non-access) of French Canadians to language facilities when they needed to interact with anglophone government institutions.
\end{abstract}

Keywords: French language, translation, Act of Union, British North America, French Canadians, linguistic policies.

\section{Introduction}

And be it enacted, That [all documents of] Legislative Council and Legislative Assembly, and of each of them respectively, and all written or printed Proceedings and Reports of Committees of the said Legislative Council and Legislative Assembly respectively, shall be in the English Language only: Provided always, that this Enactment shall not be construed to prevent translated Copies of any such Documents being made, but no such Copy shall be kept among the Records of the Legislative Council or Legislative Assembly, or be deemed in any Case to have the Force of an original Record. (Act of Union, 1840, Section 41. Emphasis added).

This article examines the linguistic situation of French Canadians after the British Conquest of 1760 and subsequent Treaty of Paris in 1763. From the theoretical and methodological standpoint of descriptive studies in translation history, I will first provide a short history of the linguistic situation in Canada, followed by a presentation and analysis of the status of the French language in the all constitutional acts which affected the governing and the use of the French language in the territory known as Quebec. I will focus more specifically on the period surrounding the Act of Union, since the linguistic situation of French Canadians changed drastically thereafter. 
The main purpose of the Act of Union, enacted in 1840, was to reverse the effect of the 1791 Constitutional Act which had split the colonial province of Quebec into the colonies of Upper and Lower Canada (so named for their relative positions on the St Lawrence River, upstream or downstream of its junction with the Quebec River). This was to form the new Province of Canada, united under a single assembly and administratively divided into Canada West (pre-union Upper Canada, post-confederation Ontario), and Canada East (preunion Lower Canada, post-confederation Quebec). Thus, in this chapter, both historical names of Lower Canada or Canada East will be used for this francophone area according to the period (i.e. pre- or post-Union) under discussion. Nevertheless, if necessary, and to avoid historical confusion, the term "French Canada" will also be used.

However, more importantly for my analysis, this was the first time that the use of French was alluded to implicitly in a Constitutional text. As stated in the above excerpt, the Act of Union established English as the only official language of the legislature and of legislative documents. It was comprised of 62 sections and over 10,000 words, yet the words "English" and "translated" are mentioned only once each. Although the Act of Union seriously undermined the linguistic rights of French Canadians, the word "French" is nowhere to be found.

\section{The status of French after the British Conquest}

Let us begin by providing a short history of the linguistic situation in Canada. Historians consider that the establishment of Samuel de Champlain's permanent colony in Quebec City, in the early seventeenth century, marks the beginning of the history of French in North America. Similarly, Anglophone religious groups, the Puritans, settled farther south during the 1620s. Thus, French and English colonies sprang up simultaneously in North America.

The Conquest of New France by British forces seriously threatened the survival of French in the colonies. Furthermore, following the American Revolutionary War (1775-1783), Loyalists (Americans loyal to the British Crown) settled in Canada, thereby increasing the English-speaking population in Canada. After the Conquest, the anglicization of Canada appeared inevitable. This, however, proved not to be the case at all, as newspapers and the legal system, in particular, would be bilingual. Moreover, French Canadians demanded the right to use the French language ${ }^{1}$.

From 1760 to 1764, New France was governed by the British Army. As Horguelin notes, the articles of Capitulation of Montreal and Quebec make no mention of language. Vaudreuil and Lévis do not address the protection of the French language. Nevertheless, French almost had official status under the military government - after all, one must govern a nation in a language its people actually understand. This was simply how things were, since no directives had been included in the Capitulations or ordered by London. (Horguelin, 1977, pp. 15-16). Even though French Canadians now faced a dimmer future, a new career was available to them: that of translator. The governors of Montreal, Quebec and Trois-Rivières appointed "secretarytranslators", whose job was to translate orders and proclamations into French (Delisle, 2011, p. 363). In this context, bilingualism and translation progressively took root in the fields of official proclamations, justice and commerce (Horguelin, 1977, p. 16).

\footnotetext{
1 In 1840, following the Act of Union, the "British Americans" (Loyalists) began calling themselves "Canadians." Then, in the English-language press, Canadians of French extraction (who until then had called themselves "Canadians") became "French Canadians," while the Loyalists remained "Canadians." Thus, anglophones were the first to use the term "French Canadian" (Arès, 1945, p. 11). Here, the term "French Canadians" will be used, regardless of the era, to avoid any confusion.
} 
In 1764, military rule was replaced by civil government. At the same time, the parallel drafting of orders was also replaced by translation in the stricter sense of the term. For Hoguelin this results in a drop in the quality of the French texts produced (1977, pp. 19-20). Those translations are included in The Quebec Gazette/la Gazette de Québec, a bilingual journal founded in 1764 (Delisle, 2011, pp. 363-364). The Gazette's translators had no experience and sadly produced French texts of questionable quality (Horguelin, 1977, p. 20).

In 1767, Guy Carleton succeeded to James Murray as governor of the Province of Quebec. Carleton was much more open than his predecessor to the linguistic needs of the francophone majority. Indeed, the following year, he appointed François Joseph Cugnet as official translator (for this role, he received 5 sterling shillings sterling per day). In 1789, he was succeeded by his son Jacques-François Cugnet. Later, Xavier de Lanaudière, Philippe Aubert de Gaspé and Edward Bowen occupied the position of official translator (Delisle, 2011, p. 364). Moreover, from 1777 to 1786, an official interpreter was assigned to the provincial courts (Delisle, 1987, p. 8).

Historically, under British rule, inhabitants of the former New France saw their religion and language protected under the law, by virtue of the 1774 Quebec Act. The Quebec Act explicitly gave French Canadians freedom of religion, permitting to practise their Catholic faith:

That his Majesty's Subjects, professing the Religion of the Church of Rome of and in the said Province of Quebec, may have, hold, and enjoy, the free Exercise of the Religion of the Church of Rome [...] and that the Clergy of the said Church may hold, receive, and enjoy, their accustomed Dues and Rights, with respect to such Persons only as shall profess the said Religion. (Quebec Act, 1774, section $5)$.

This provision implicitly protected the use of the French language because Catholicism was the religion of the French-speaking population. In this way, the provision unofficially recognized francophone religious life, as members of the clergy spoke French and also taught in that language. Moreover, the Quebec Act restored French civil law, which allowed for the use of French in the courts for civil matters (ibid., section 8). The restoration of French civil law would greatly contribute to the development of the petite bourgeoisie, and professionals such as law clerks, lawyers, notaries and judges flourished.

The use of the French language was officially recognized for the first time in the Constitutional Act of 1791. As noted above, one of the Act's major provisions was the splitting in two of the Province of Quebec, which led to the creation of Lower and Upper Canada, separated by the Ottawa River. Sections 24 and 29 stated that voters or members of the Legislative Council or Assembly of Lower Canada would be allowed to take an oath in either English or French (Constitutional Act 1791). Therefore, we may conclude that the Constitutional Act implicitly recognized that the French language was already being used in the Legislative Assembly and Legislative Council of Lower Canada. Sections 24 and 35 reiterated that the people of Lower Canada could practise the Catholic faith and be subject to civil law, tacitly guaranteeing the use of French in Church and in civil courts.

In 1793, the Legislative Assembly of Lower Canada voted on a resolution in support of the French translation of laws. Though passed, it was never actually implemented, even though a translator was appointed (Delisle, 1987, p. 9). Nevertheless, the situation progressed positively until, with the assignation of two translators to the Legislative Assembly in 1809, the laws of the colony were eventually translated into French (Delisle, 2011, p. 364). 
As Jacques Gouin explains, translation in Canada from 1791 to 1812 was mainly entrusted to the former seigneurial elites ${ }^{2}$. However, he notes that from 1789 up until 1850, the quality of translation steadily diminished. In his view, it is because translations were increasingly assigned to British nationals (Gouin, 1977, p. 29).

As we have seen, after the surrender of New France to British forces in 1760, no British law officially recognized French as the language of the inhabitants of the Province of Quebec (Lower Canada). While the Quebec Act of 1774 guaranteed freedom of religion and upheld the civil code, thereby allowing the use of French in churches and in the courts, French remained a language without official status.

Against this backdrop, French Canadians and English Canadians inhabited separate worlds. The tensions between the two groups ran deep, and there would be little contact between them before the nineteenth century. As a result of the Conquest, the economy fell into the hands of the English, and the industrialization of Quebec was carried out by large British companies. English thus became the language of the economy and of trade (Corbeil, 1974, pp. 5-7). The two societies evolved separately: "From this point forward, contacts and alliances between the two groups are not only rare but also tense; it is the creation of the "two solitudes'." (Plourde, 2000, p. 56, our translation).

\section{The Patriotes Rebellions and the 92 Resolutions}

The rise of British power - through immigration and industrialization - in Quebec served as a catalyst for nationalist discourse and the emergence of organizations such as the Société Saint-Jean Baptiste and the Parti Patriote. After the War of 1812, the elected Assembly of Lower Canada was dominated by representatives from the French-Canadian middle class. The emergence of this new professional elite led to the development of a national consciousness within the francophone population. Elected to the Assembly in 1815, Louis Joseph Papineau became the leader of the Parti Canadien, which would become the Parti Patriote in 1826. The Parti Canadien sought greater independence from the Church, especially with regard to education, and from the British Government. Papineau demanded the right to spend the revenue raised in Lower Canada and challenged the authority of an appointed Legislative Council. In short, the Patriotes were seeking the sovereignty of the Legislative Assembly. They also fought to safeguard the French language (Dumont, 1993, pp. 188-9). During the 1820s, the demands of the Assembly of Lower Canada were met with resistance from the Governor General, the Earl of Dalhousie. The situation continued to deteriorate until the Rebellions (Buckner, 2015, par. 3-5), despite the appointment of conciliatory governors.

The French-Canadian ethnic majority began to be undermined in the $1830 \mathrm{~s}$ by the demographic increase of the English-speaking population of British origin. A wave of immigration brought epidemics, such as cholera, to Lower Canada, creating fear and xenophobia within the francophone population. Sketched by Papineau, drafted by Augustin-Nobert Morin and presented by Elzéar Bédard in February 1834, the 92 Resolutions of the Parti Patriote embodied a point of no return in the political destiny of the British colony of Lower Canada. In essence, the resolutions constituted a long list of demands for political reform, the main one being that for Responsible Government (Lamonde, 2000, pp. 122-3). Resolutions 51-55 concerned the defence of the rights and language of the French Canadian people, and denounced the lack of

\footnotetext{
2 The seigneurial system was an institutional form system of land distribution in New France (established in 1627 and abolished officially in 1854). Inspired by the feudal system, the habitant (tenant) occupies part of the land of the seigneur to whom he pays certain dues. The seigneurs formed a privileged class.
} 
language planning. Resolution 52 clearly stated that because of their use of the French language, French Canadians had been not only marginalized, but also ridiculed and rendered politically inferior. Papineau claimed that they were proud of their French origin, which formed the basis of the civil and ecclesiastical laws of Canada:

Resolved, That since a circumstance, which did not depend upon choice of the majority of the people, their French origin and their use of the French language, has been made by the colonial authorities a pretext for abuse, for exclusion, for political inferiority, for a separation of the rights and interests; this House now appeals to the justice of His Majesty's Government and of Parliament, and to the honour of the people of England; that the majority of the inhabitants of this country are in nowise disposed to repudiate any one of the advantages they derive from their origin and from their descent from the French nation, which, with regard to the progress of which it has been the cause in civilization, in the sciences, in letters, and the arts, has never been behind the British nation, and is now the worthy rival of the latter in the advancement of the cause of liberty and of the science of Government; from which this country derives the greater portion of its civil and ecclesiastical law, and of its scholastic and charitable institutions, and of the religion, language, habits, manners and customs of the great majority of its inhabitants. (Papineau 1834, résolution 52; English Translation: Kennedy, 1930, pp. 280-281)

A few points are key in this resolution. Papineau and his followers stated that French Canadians did not choose to be conquered by British forces. He also stated that his people were subject to discrimination because of a condition beyond their control: their French language and culture. He called upon the British Crown and Parliament to rectify the situation. French Canadians, he insisted, would under no circumstance turn their backs on their French culture and the French language. The French language should be recognized, he urged, along with a certain francophone way of life, including schools, charitable institutions, religion, habits and beliefs of the French-Canadian population. However, as Yvan Lamonde explains, Papineau and other public figures of Lower Canada did not cling to their relationship with France. They wished to protect their language and their traditions against a perceived English political antagonist (Lamonde, 1997, p. 10). Papineau had a strong attachment to the French language and personally fought for improvement of the justice system and for the use of French in courts of law. He believed that it was not necessary to stop speaking French in order to know and love the Constitution (ibid., p. 30). In other words, for Papineau the French language was an integral part of the Lower Canadian identity.

In March 1834, the resolutions were sent to London, where they were ignored for three years. During this time, the political situation in Lower Canada became increasingly tense as the Legislative Assembly (led by the Parti Patriote) paralyzed the colonial government. The consent of the Assembly was required for the use of public funds. Furthermore, clashes between extremists within both the Parti Patriote and the British Party exposed the profound ethnic divisions. In March 1837, the British Parliament published its official response to the Patriotes' 92 Resolutions, in the form of 10 Resolutions drafted by British Colonial Secretary Lord John Russell.

In his Resolutions, Lord Russell clearly rejected the transformation of the Legislative Council into an elected body (one of Parti Patriote's key demands). There was no mention whatsoever of the linguistic rights of the French Canadians. Once again, this issue was simply overlooked (Russell, 1837). In the spring of 1837, as the Legislative Assembly was no longer in session, the Parti Patriote organized public assemblies and protest rallies across Lower Canada. The public protests were banned by Governor Gosford and the political climate deteriorated rapidly throughout the fall. French-Canadian patriotic groups, such as the Fils de la Liberté, clashed with British troops, mainly in the countryside. 
On November 16, several Patriotes leaders were arrested by British troops.. Several hundred rebels were killed or wounded during the fighting, and many more were captured by British forces, while Papineau and other important figures of the Patriotes were forced to flee to the United States. The 1837 rebellions of Lower Canada would become ingrained in the collective imagination of French Canada (and later Quebec).

\section{The Durham Report}

Following the failure of the 1837 Patriotes Rebellions, the linguistic situation of French Canadians deteriorated considerably (Dumont, 1993, p. 205). The French-Canadian political elite was not only defeated, but had also lost all credibility. English increasingly gained ground: British immigration grew in Lower Canada, and Montreal became an essentially anglophone city. The Constitution of 1791 was suspended on March 27, 1838, and a Special Council put in place. In the Montreal district, habeas corpus was suspended from April to August 1838. The British statesman, John George Lambton, first Earl of Durham, arrived in Quebec City in April, staying until November. His amnesty measures toward prisoners angered London and ultimately led to his resignation.

In 1839, Lord Durham, who considered French Canadians to be a people with neither a history nor a literature, tabled the so-called 'Durham Report', in which he advocated their assimilation (Biron et al., 2007, p. 57). To his mind, the English population was decidedly superior to the French Canadians whom he depicted as: "An utterly uneducated and singularly inert population, implicitly obeying leaders who ruled them by the influence of a blind confidence and narrow national prejudices [...]" (Durham, 1839, p. 11). His view of the colony's British population, on the other hand, was completely different and much more positive overall:

I have found the main body of the English population, consisting of hardy farmers and humble mechanics, composing a very independent, not very manageable, and sometimes, a rather turbulent democracy. Although constantly professing a somewhat extravagant loyalty and high prerogative doctrines, I found them very determined on maintaining, in their own persons, a great respect for popular rights, and singularly ready to enforce their wishes by the strongest means of constitutional pressure on the government. (ibid., p.11)

Durham went much further, however, qualifying the French-Canadian farmers or the habitants, as ignorant and illiterate: "no means of instruction have ever been provided for them, and they are almost universally destitute of the qualifications even of reading and writing" (ibid., p. 13). He believed that the French Canadian majority's lack of education had made them ungovernable and was responsible for the political unrest which climaxed with the Patriotes Rebellions.

Durham seemed very conscious of the social differences between the French Canadians and the English in Lower Canada. In his view, English and French speakers were not only educated separately, but their respective languages led to different ways of thinking which inhibited any effort towards mutual comprehension. The differences were so profound that they could easily be perceived in the press, insofar as articles were written with the goal of being incomprehensible to the other group. More importantly, he stated that there was very little contact between the two peoples at school, in business and in the social sphere. He highlighted the fact that the two linguistic groups evolved along parallel paths, their only meeting ground being the jury box, and even then never by choice (ibid., pp. 18-19). 
A few pages later, Durham criticized the course of action taken by the British Government. The creation of two provinces, Upper and Lower Canada, was a mistake. In other words, allowing Lower Canada to be a French community in which the French Canadians kept their language and institutions was unwise, especially when one considered that London also encouraged English emigration to the province. Moreover, French civil law and the "legal provision for the Catholic clergy" were limited to the French portions of Lower Canada (ibid., p. 30). In other words, Lower Canada was not the FrenchCanadian entity it was initially designed to be. Likewise, according to Durham, constant contact with the English population which settled in the Townships was the cause of conflict, as French Canadians experienced jealousy and animosity towards a people who were clearly superior to them. Durham believed that the English population would soon be greater than the FrenchCanadian population, even in Lower Canada, and that the former was already superior in "knowledge, energy, enterprise and wealth." He felt, therefore, that it would be a mistake to try to preserve a French-Canadian identity (ibid., p. 31).

In the final analysis, Lord Durham had a very demeaning view of French Canadians, their language and their institutions. His attitude was decidedly colonialist and, as stated above, he believed that at the root of the problem lay the fact that French Canadians had up to this point preserved their unique - and distinctly French - identity:

There can hardly be conceived a nationality more destitute of all that can invigorate and elevate a people than that which is exhibited by the descendant of the French in Lower Canada, owing to their retaining their peculiar language and manners. They are a people with no history, and no literature. (ibid., pp. 126-7, our italics)

Durham's solution was as simple as it was shocking: the assimilation of the French Canadians. Although he was aware that assimilation would not happen overnight, he was convinced that everything had to be put in place for it to happen; "that in any plan which may be adopted for the future management of Lower Canada, the first object ought to be that of making it an English Province" (ibid., p. 127). In order to do so, he placed all governing power in the hands of the English-speaking population: "Lower Canada must be governed now, as it must be hereafter, by an English population." Durham's solution was what he called a "federal union" or the Union of Upper and Lower Canada, because, once combined, the English-speaking population of both Canadas would outnumber the French Canadians and enable governance by an English majority: "I believe that tranquility can only be restored, by subjecting the Province to the vigorous rule of an English majority: and that the only efficacious Government would be that formed by a legislative union" (ibid., p. 131).

As we have seen, Lord Durham was a British colonialist who strongly believed in the superiority of the English population over the French Canadians. In the end, since French Canadians were "a people with no history, and no literature," their best option was to adopt the English language and way of life.

\section{The union of Upper and Lower Canada: English as the sole language}

The Act of Union was passed by the British Government in July 1840 and proclaimed in February of the following year. As mentioned above, the Act of Union unified Upper and Lower Canada under one government, thereby creating the Province of Canada. Under the Act of Union, London did not grant responsible government (i.e. representation by population, the number of representatives being proportional to the population), as each former province had 42 representatives in the new entity's unified Legislative Assembly. This 
was unfair to Canada East, whose population was larger than that of Canada West. In concrete terms, it meant that the representatives of Canada West could form alliances with the Anglophone representatives of Canada East and therefore undermine the francophone population.

The desire to assimilate the French-speaking population was visible. Significantly, this was the first time the use of French was officially banned in a constitutional document. The Act of Union established English as the only official language of the legislature and of legislative documents. It also made it impossible for francophones to protect their language and their institutions in the Assembly, given that the English held the majority of the votes. Not surprisingly, the opposition to the Union was universal within the FrenchCanadian population. As Étienne Parent wrote in Le Canadien on January 27, 1840: "[The union's] goal is nothing short of stripping us of what is dearest to us: our langue, our customs, our rights, in other words, our nationality." (Our translation). The francophone political class was very conscious of the fact that the Union could mean the end of French-Canadian identity and lead to the disappearance of the French language.

Étienne Parent reacted swiftly and tabled a bill in 1841: An Act to provide for the translation into the French language of the Laws of this Province, and for other purposes connected therewith. This bill demanded the French translation of all the laws of the new Canadian Parliament as well as all the laws concerning Canada emanating from the British Parliament. The bill was adopted on September 18, 1841.

The Catholic clergy was also fiercely opposed to the Union, fearing that it would not only "anglicize" French Canadians, but more importantly "decatholicize" them and cause the erosion of the church's power (Lamonde, 2000, p. 285). The clergy's opposition to the Rebellions had resulted in London giving legal status to the Catholic Church in 1839, which allowed it to invest in and possess goods without danger of confiscation. The clergy took advantage of the situation to tighten its grip on education, the press and public welfare (Lemire and Saint-Jacques, 1999, p. XV). This was the birth of ultramontanism.

While one had the right to argue for secular education, in Canada East ultramontanism had one undeniably positive effect: education was to be provided in French. In the end, the control the Catholic Church managed to exercise over the French-Canadian population probably saved their language. Schools, hospitals and charitable institutions were all to be run by the clergy. The Church also had its own newspapers and dictated what could and could not be read, going so far as to produce a recommended reading list. From the 1840s onwards, libraries were threatened by ecclesiastic censorship, which - among other things - tried to prevent a project to build a public library in Montreal (Robert, 1989, p. 107). The French language was saved, but French-Canadian identity was radically altered as a result of the clergy's strong hold on society.

The other factor that would save the French language in Canada was the friendship between Louis Hippolyte Lafontaine and Robert Baldwin. Lafontaine and Baldwin formed a government in 1842 and again in 1848. Their leadership had profound effects on public administration and the legal system, and they are remembered as the architects of responsible government (Colombo, 2011, p. 52). In September 1842, Lafontaine accepted the nomination for Attorney General. He addressed the members of the Assembly in French, even though until then all debates had taken place in English only:

I refuse to submit myself to speaking the English language [...] Even if my knowledge of the English language was as familiar as my knowledge of the French language, I would still make this address in the language of my French Canadian compatriot if only to solemnly protest against this cruel injustice of this part of the Act of Union which forbids the mother tongue of half of the population of Canada. I owe it to my compatriots, I owe it to myself... If we must succumb, we will 
succumb, but we will command respect. (Lafontaine, cited in Groulx, 1960, p. 190. Our translation)

Lafontaine therefore put his foot down: he would speak French in the Assembly even if it might displease certain members. To summarize, he firmly believed that it was his duty as a French Canadian to use his mother tongue. It was a matter of respect: self-respect, but also demanding the respect of his English neighbours. In this context, French was once again used in the Assembly, even though it had no official status.

In December 1844, Papineau - who had just returned from exile announced his intention to demand the revocation of section 41 of the Act of Union, the infamous provision that had made English the only official language of Canada. Although Papineau was a controversial political figure, his actions were met with support from the other members of Parliament. The final text was adopted on February 21, 1845 by the unified Legislative Assembly, approved by the Legislative Council, and sent to London in March. On January 18, 1848, Lord Elgin (Governor of Canada) delivered the Speech from the Throne in English and in French, in which he announced that the British Parliament had passed a law revoking Section 41 of the Act of Union (Plourde, 2000 , p. 70). It is important to stress, however, that section 41 was not modified in order to recognize French as an official language of Canada. The section was simply revoked, meaning that it was erased from the law. Once again, the French language was left in a constitutional vacuum. This led to the reinstauration of parliamentary bilingualism, a move back to the non-legislative status of both the French and the English language that had been in place from the Conquest (1763) until the Act of Union (1840).

Starting in the 1850s, translation saw a revival. In 1854, Antoine GérinLajoie suggested a reorganization of translation within the Legislative Assembly. Translation was divided into three sections: 1) laws, 2) documents, 3) votes and proceedings (Delisle, 1987, pp. 10-11, and 2011, p. 364). The Legislative Assembly's translation bureau was made up of seven people. Although the team itself was admittedly quite small, Gérin-Lajoie worked towards the recognition of translation generally. François-Xavier Garneau, best known for his History of Canada (1852), was a translator at the Legislative Assembly. (Gouin, 1977, pp. 30-31).

\section{The 1867 British North America Act: French appears in a legal text}

In 1867, the British government passed the British North America Act, subsequently known as the Constitution Act 1867, which created the Canadian Confederation by bringing together the British colonies of Nova Scotia, New Brunswick and the Province of Canada (the latter comprised of Canada West and Canada East, which were thenceforward known respectively as Ontario and Quebec). It was the first time French was recognized as an official language of Canada and Quebec. In concrete terms, this meant that members of the Legislature would have the right to use either French or English in the Parliament of Canada and in the Legislative Assembly of Quebec. Moreover, both languages could be used in cases brought before the federal courts of Canada and all the courts of Quebec. The entire linguistic debate that had been going on for a century was encapsulated in one section of the Constitution Act 1867:

133. Either the English or the French Language may be used by any Person in the Debates of the Houses of the Parliament of Canada and of the Houses of the Legislature of Quebec; and both those Languages shall be used in the respective Records and Journals of those Houses; and either of those Languages may be used 
by any Person or in any Pleading or Process in or issuing from any Court of Canada established under this Act, and in or from all or any of the Courts of Quebec.

The Acts of the Parliament of Canada and of the Legislature of Quebec shall be printed and published in both those Languages. (Constitution Act 1867, section 133)

This was the first step towards official bilingualism as we know it today in Canada. The significance of section 133 lies in the fact that it contains the first occurrence of the word "French" in a constitutional document, thereby according official recognition to the French language for the first time since the 1763 British Conquest. Nevertheless, it would be another 100 years before the enactment of the Official Languages Act (1969).

\section{The place of translation in constitutional acts and orders}

In the above section, I summarized the status of the French language in British North America, looking periodically at the translation practices that emerged as a result of the changing political and linguistic context. I should now like to briefly focus on the place of translation in the Constitutional Acts and Orders which were presented in this article. Indeed, of all the documents examined above (Quebec Act, Act of Union, Constitution Act, 1867, Official Languages Act, Ninety-Two Resolutions of the Legislative Assembly of Lower Canada, Report on the Affairs of British North America), only the Act of Union references translation. The word "translated" appears once, in section 41:

Provided always, that this Enactment shall not be construed to prevent translated Copies of any such Documents being made, but no such Copy shall be kept among the Records of the Legislative Council or Legislative Assembly, or be deemed in any Case to have the Force of an original Record. (Act of Union, 1840, section 41. Emphasis added).

The Act of Union provides readers with insight into the translation practices used for texts produced by the Assembly and the Legislative Council. Clearly, through their non-official status, translated texts were perceived as derivative and inferior. Moreover, because English had sole official status, the unspecified default direction of translation was into French - that is, the language's existence had only implicit recognition. The inferior status of the French language and of French translations is made clear when it is stated in a constitutional text that translations would not be kept or considered official.

\section{Translation and the English criminal justice system}

In the territory of the province of Quebec, the criminal justice system is a key example of how the English and the French languages and their respective translation interacted. Indeed, after the Conquest of 1760 and the implementation of English common law, the criminal justice system resorted exclusively to the English language, which did result in more translation. Justices of the peace were the basis of the new judicial system. For the most part, justices of the peace were not educated in law. Thus, in order to carry out their duties, the magistrates of Lower Canada referred to handbooks such as The Justice of Peace and Parish Officer by Richard Burn (Fyson, 2006, pp. 123-4). Burn's handbook was only available in English, which was a major obstacle for many of the justices of the peace in Lower Canada. As a result, Joseph-François Perrault undertook the translation, with the aim of disseminating it through subscription: "I translated from 'Burns Justice,' the chapters which are most needed by my fellow citizens to perform their duties as magistrates, jurors and constables [...]" (Casgrain, 1898, p. 54, our translation). However, despite the 
importance of publishing French versions of available English legal books and a rather large subscription base, Perrault only produced a partial translation, published in 1789 (Fyson, 2006, p. 124; Casgrain, 1898, p. 162).

According to Fyson, the translation - which included the powers and duties of justices of the peace, as well as general procedures for arrest warrants and admissions, but excluded infraction descriptions and comments - was very useful, and he suggests that owning a copy influenced the competence of justices of the peace (Fyson, 2006, p. 124). Perreault also proposed translations for many English legal terms in his 1814 book, Questions et réponses, which have subsequently been described as follows:

His suggestions were sometimes perfectly sound, yet at other times quite awkward. "Indictement," "assault et batterie," "nuisance," "offense," "quartiers généraux de la paix," "affidavit," and "termes de la cour" were not his most clever findings, but these expressions lasted; they are found not only in legal literature and the language of lawyers, but in legal texts, over the past century. (Morel, 1976, p. 115-6, my translation).

Generally speaking, it was not difficult to access legislative texts in Lower Canada before the Act of Union: acts and colonial orders were published in English and French in the Gazette du Québec (Fyson, 2006, pp. 124-5). According to Morel, however, monolingual French Canadians saw the criminal justice system as a closed-off world, until Jacques Crémazie's translation Les lois criminelles anglaises, traduites et compilées de Blackstone, Chitty, Russel et autres criminalistes anglais et telles que suivies en Canada was published in 1842. Despite the efforts of Perrault and Crémazie, case law, the cornerstone of English criminal law, was only available in English (Morel, 1976, p. 115).

With regard to Francophones taking the bench, Fyson clearly states that bilingualism was ensured before nominating a French-Canadian justice of the peace. G. W. Allsopp a businessman, seigneur and politician who was appointed justice of the peace in 1794, stressed the importance the importance of speaking French: "altho' the English language is a desirable acquirement the French is the most necessary in the country parishes" (Allsopp, cited in Fyson, 2006, p. 89). In fact, francophone justices of the peace were particularly active: in Montreal, they represented between $40 \%$ and $50 \%$ of all justices of the peace and were responsible for an even greater proportion of lawful processes (Fyson, 2006, p. 114).

That said, English continued to be the language of the criminal justice system, which was perceived by many inhabitants to be inaccessible to the average French Canadian (by contrast, most francophone law professionals worked in the civil courts). However, Fyson refines this perception, since the Court of King's Bench did accommodate francophones to some degree. Thus, while most documents and procedures were in English, francophone witnesses could provide testimony and be cross-examined in French, although indictments were always written in English. Furthermore, a large number of justices of the peace used French if it was the language spoken by the parties, particularly in rural areas; however, not all did so, and many opposed its use in the criminal justice system, particularly during the very tense 1820s and 1830s (ibid., pp. 249-53). Accordingly, the best-case scenario for French Canadians who had to face the criminal justice system was that their case might be tried in French.

In 1849, a law was passed that stipulated that English was the only language of the Court of King's Bench, rendering the use of English or French at the justice's discretion no longer applicable (Morel, 1976, p. 118). A worstcase scenario therefore becomes the norm for French Canadians facing the justice system: though they might still hope to address the court in French, post1849 they would likely be unable to understand the proceedings because all matters were tried in English. The lack of translation and interpretation resulted 
in an inaccessible criminal justice system for French Canadians; it also confirmed the inferior status of French and francophones.

\section{Conclusion}

After the Conquest, no British document or law officially recognized the French language as the language of the inhabitants of the Province of Quebec (Lower Canada) - the territory we now call Quebec. However, as we have seen, the French language lived on in the territory. Moreover, the coexistence of the English and French languages enabled the birth of a new profession and a new reality in the colony: translator and translation. Although not fully recognized or organized, the practice was very much alive from day one of English governance in the former New France.

Furthermore, French Canadians fought diligently for their linguistic rights. In 1777, the Quebec Act provided inhabitants with the constitutional right to freedom of religion and re-established French civil law (Quebec Act, 1774, sections 5, 7, and 8). The Quebec Act unofficially recognized the use of French as the language of the Church and civil courts. Members of the Parti Patriote fought for the rights of French-speaking Canadians, which led to the 1837 Lower Canada rebellions. This led to the production of the "Durham Report" which perceived French Canadians as "a people with no history, and no literature," who should be assimilated to the English way of life. As a result, the Act of Union (1840) officially prohibited the use of French and, in fact, recognized English as the sole language of the legislature (Act of Union, 1840, section 41). London's ban on the French language lasted for a period of eight years. During that time, key political figures such as Louis Hippolyte Lafontaine defended their right to speak French in the Legislative Assembly. Moreover, this era of political turmoil led to the rise of ultramontanism. The Church successfully sought control of education, the press and public welfare; greatly contributing to the preservation of the French language.

Despite the British government's effort to repress the French language and assimilate the francophone population, the language survived even in the most English of institutions: the criminal law courts. Criminal law manuals were made available in French through translation. Many magistrates spoke French and allowed it to be used in the courts when it was the language of both parties. Francophones also had the right to testify in their language. French Canadians fought to preserve their language and their fight was successful: the Constitution Act, 1867 recognized French as the language of the newly formed Dominion of Canada and newly formed province of Quebec. As a result, French and English could be used by the Parliament of Canada and the Legislature of Quebec (Constitution Act, 1867, section 133).

\section{References}

Arès, R. (1945). Notre question nationale [Our National Question] (Vol. 3). Montreal: Éditions de l'Action nationale.

Biron, M., Dumont, F., \& Nardout-Lafarge, E. (2007). Histoire de la littérature québécoise [History of Quebec literature]. Montreal: Boréal.

British Parliament (1774). Quebec Act of 1774. An Act for making more effectual Provision for the Government of the Province of Quebec in North America. Retrieved from: https://slmc.uottawa.ca/?q=leg_quebec_Act

British Parliament (1791). Constitutional Act. [...] An Act for making more effectual Provision for the Government of the Province of Quebec, in North America; and to make further Provision for the Government of the said Province. Retrieved from: https://slmc.uottawa.ca/?q=leg_constitution_act_1791 
British Parliament (1840). The Act of Union. An Act to reunite the Provinces of Upper and Lower Canada, and for the Government of Canada. July 23, 1840. Retrieved from: https://slmc.uottawa.ca/?q=leg_union_Act

British Parliament (1867). Constitution Act 1867. An Act for the Union of Canada, Nova Scotia, and New Brunswick, and the Government thereof; and for Purposes connected therewith. Retrieved from http://laws-lois.justice.gc.ca/eng/const/page7.html\#h-29

Buckner, P.A. (2015). Rebellion in Lower Canada. The Canadian encyclopedia. Retrieved from: http://thecanadianencyclopedia.ca/en/article/rebellion-in-lowercanada/

Casgrain, H.-R. (1898). La vie de Joseph-François Perreault surnommé le père de l'éducation du peuple canadien [The Life of Joseph-François Perreault known as the father of education of the Canadian people]. Québec: C. Darveau imprimeur et photo-graveur. Retrieved from: https://archive.org/details/cihm_00540/page/n5

Colombo, J.-R. (2011). Fascinating Canada: A book of questions and answers. Toronto: Dundurn Press.

Corbeil, J.-C. (1974). Essai sur l'origine historique de la situation linguistique du Québec [Essay on the historical origin of the linguistic situation of Quebec]. Éditeur Officiel du Québec.

Crémazie, J. (1842). Les lois criminelles anglaises, traduites et compilées de Blackstone, Chitty, Russel et autres criminalistes anglais et telles que suivies en Canada [English Criminal Laws, translated and gathered from Blackstone, Chitty, Russel and other English lawyers, as they are enacted in Canada]. Québec: Imprimerie de Frechette et cie. Retrieved from: https://books.google.ca/books? $\mathrm{id}=\mathrm{dh} 4 \mathrm{eAAAAMAAJ} \& \mathrm{dq}=\% 22 \mathrm{Jacques}+\mathrm{Cr} \% \mathrm{C} 3 \% \mathrm{~A} 9$ mazie $\% 22+$ traduction $\&$ so urce=gbs_navlinks_s

Delisle, J. (1987). La traduction au Canada - Translation in Canada 1534-1984. Ottawa: Les Presses de l'Université d'Ottawa.

Delisle, J. (2011). Canadian Tradition. In M. Baker \& G. Saldanha (Eds.), The Routledge encyclopedia of Translation Studies (pp. 362-369). London and New York: Routledge.

Dumont, F. (1993). Genèse de la société québécoise [Genesis of Quebec Society]. Montreal: Boréal.

Fyson, D. (2006). Magistrates, police, and people: Everyday criminal justice in Quebec and Lower Canada, 1764-1837. Toronto: University of Toronto Press.

Gouin, J. (1977). La traduction au Canada de 1791 à 1867 [Translation in Canada, from 1791 to 1867$]$. Meta, 22(1), 26-32.

Groulx, L. (1960). Histoire du Canada français [History of French-Canada]. Montreal: Fides.

Horguelin, P. A. (1977). Les premiers traducteurs (1760 à 1791) [The first translators (1760-1791)]. Meta, 22(1), 15-25.

Kennedy, W. P. M. (1930). Statutes, treaties and documents of the Canadian Constitution, 1713- 1929. Toronto: Oxford University Press.

Lambton, J. (Earl of Durham) (1839). Report on the Affairs of British North America. Toronto: Robert Stanton.

Lamonde, Y. (1997). Conscience coloniale et conscience internationale dans les écrits publics de Louis-Joseph Papineau (1815-1839) [Colonial awareness and international awareness in the public writings of Louis-Joseph Papineau (18151839)]. Revue d'histoire de l'Amérique française, 51(1), 3-37.

Lamonde, Y. (2000). Histoire sociale des idées au Québec: 1760-1896 [Social History of Ideas in Quebec: 1760-1896]. Montreal: Fides.

Lemire, M., \& Saint-Jacques, D. (1999). La vie littéraire au Québec [Literary life in Quebec] (Vol. 4). Sainte-Foy: Les Presses de l'Université Laval.

Morel, A. (1976). La réception du droit criminel anglais au Québec 1760-1892. Rapport soumis à la commission de réforme du droit du Canada [Reception of English criminal law in Quebec 1760-1892. Report submitted to The Law Reform Commission of Canada]. Montreal: Faculté de droit, Université de Montréal.

Papineau, L.-J. (1834). Les 92 résolutions de l'Assemblée législative du Bas-Canada [92 Resolutions of the Legislative Assembly of Lower Canada]. La Bibliothèque électronique du Québec. Retrieved from: https://beq.ebooksgratuits.com/pdf/ 92resolutions.pdf 
Plourde, M. (2000). Le français au Québec: 400 ans d'histoire et de vie [French in Quebec: 400 years of History and Life]. Anjou: Fides.

Robert, L. (1989). L'institution du littéraire au Québec [Establishment of the literary in Quebec]. Quebec: Les Presses de l'Université Laval.

Russell, J. (1837). Resolutions Intended to be Proposed by Lord John Russell, in a Committee of the Whole House, Relative to the Affairs of Canada. Retrieved from: http://eco.canadiana.ca/view/oocihm.9_01092/3?r=0\&s=1 